\title{
LOCAL ECONOMIC IMPACT OF THE WHITE NIGHT FESTIVAL IN KOŠICE
}

\author{
Peter Džupka, Miriam Šebová
}

\section{Introduction}

Culture, in the way of cultural infrastructure, events and cultural heritage, generates a series of economic effects, both direct effects in the cultural sector (employment, production etc.) and induced effects in other sectors of the local economy (construction, tourism, transport, etc.) (Herrero et al., 2006). The promotion and development of the cultural sector has gained increasing popularity as a medium of urban transformation. This concept has been labelled "culture led urban regeneration" (Garcia, 2004; Lähdesmäki, 2012). The best practises were popularized by cities such as Glasgow, Liverpool, Barcelona and Bilbao. This phenomenon of cultural renaissance accompanied by the vital cultural participation of residents and booming cultural tourism became a stimulus for European cities to apply for the European Capital of Culture (ECoC) title. Košice, the second largest city in Slovakia with around 250,000 inhabitants, was designated for the title ECoC 2013 in 2008 . The designation started the process of cultural progress led by the building of new cultural infrastructure (e.g. Kunsthalle) and the organisation of various cultural events. The largest and most popular events have been the open space festivals especially the summer art festival and White night.

Cultural festivals can be described as events held on a regular basis with evidence of high cultural value. They usually involve a specific programme with culture which differs from year to year (Palma et al., 2013). A more comprehensive definition of festivals has been given by the South Australian Tourism Commission: "Festivals are celebrations of something the local community wishes to share and which involves the public as participants in the experience. Festivals must have as a prime objective a maximum amount of people participation, which must be an experience that is different from or broader than day to day living." (SATC, 1997 In Arcodia, Whitford, 2006).

The objective of the current paper is to evaluate the economic impact of the all-night arts festival the White night (from the original French title Nuit Blanche) which is the spinoff of the Košice European Capital of Culture 2013. The festival is the largest open-space cultural event ever organised in the city. It was inspired by the international Nuit Blanche network, which is associated with several cities worldwide. Museums, art galleries and other cultural institutions are open with free entrance at night time. The centre of the city is turned into an "open art gallery", providing space for art installations and performances (music, film, dance etc.) all mainly linked to modern art. The Nuit Blanche concept has been followed by many European capital cities (Rome, Amsterdam, Brussels, Copenhagen, Bucharest, Madrid) and has also spread outside Europe to New York, Melbourne and Tokyo. Only a few provincial cities have gained the licence to organise this prestigious event because of the demanding organisation and high quality standard of arts performances. The organisers of the Košice European Capital of Culture 2013 included this special event in the cultural city programme with the clear objective of attracting tourists and redefining the city image - from an old industrial city to a modern city with a vibrant cultural life. The paper is organised into two parts. The first part is a review of the literature in the field of economic impact studies and used methodology. The second part contains the case study about the economic impact of the White night which draws on a unique dataset obtained from a survey carried out amongst the attendees. The research was conducted during 2012 and 2013. 


\section{The Rationale for the Economic Impact Assessment of Cultural Events}

Cultural festivals and special events can play a significant role in community life and economic development. Their popularity is based on the increased importance of cultural tourism as one of the largest and fastest growing global tourism markets in recent years. Cultural tourism is viewed as a "higher form" of tourism because of the assumption that visitors have a higher education and better behaviour (OECD, 2009; Richards, 2005). Cultural events have the potential to generate diverse benefits, ranging from their economic contribution (additional income to the local economy and employment), to the social involvement of the community. Their link to a specific area means that they can be perceived as tourist attractions that revitalize local traditions, positively impact living standards as well as the image of the city or region (Palma et al., 2013; Slach et al. 2013; Sucháček \& Sed'a, 2011).

Cultural festivals have grown in their amount, popularity and variety in recent years. As a result of their growing importance in regional development, there are a number of scholars working on developing valid models to evaluate the economic aspects of the festivals in their host communities.

Most cultural economics research has focused on economic impact assessment (EIA), economic footprint analysis or CBA (Gazel \& Schwer, 1997; Fleischer \& Felsenstein, 2002; Gursoy et al., 2004; (Estonian Institute of Economic Research, 2012). There are other studies which have valuated cultural festivals using methods such as contingent valuation, conjoint analysis, hedonic pricing models or travel costs methods which estimate the socio-economic impacts of events (Sanz et al., 2003; Navrud et al, 2002; Castiglione \& Infante, 2015). There have been few published studies which have focused on the social, cultural, and/or political impacts of festivals (e.g. Guetzkow, 2002; Arcodia \& Whitford, 2006; Quinn, 2006) or which have analysed the determinants of cultural participation in depth (Palma et al., 2013).

O'Sullivan and Jackson (2002) have however, developed a festival typology. They have identified three festival types: homegrown, tourist-tempter and big bang events.
A "home-grown" festival is essentially a small scale, bottom-up event which is run by one or more volunteers for the benefits of the locality. A "tourist-tempter" festival is one that is aimed specifically at attracting visitors to stimulate local economic development. A "big-bang" festival is essentially a marketing tool that promotes a myriad of related activities over a defined geographic area (Hackbert \& College, 2009).

The rationale for measuring the economic impact of cultural events such as festivals is based on several motives. There is an increasing interest in identifying and understanding the various costs and benefits associated with festivals. The economic impact analyses serve as tools to get accurate data which is useful in further economic analyses (e.g. CBA). The contribution of economic impact analysis is the provision of information about the structure and amount of attendees especially at ungated events without any sold tickets. The calculation of the additional economic contribution of an event into the local economy can strengthen the event marketing and its advocacy. The advocacy purpose could be associated with the temptation to calculate the size of the local economic impact (e.g. GDP contribution, jobs created) and make it as large as possible which has been criticized in the research community (e.g. Stanley et al., 2000; Crompton, 2010; Tyrrel \& Johnston, 2011). The level of economic impact could easily be overestimated if a carefully structured working methodology has not been used. The number could be overestimated if the organisers claim that all or most of the visitors' expenditure was motivated by the event. In order to avoid this problem the methodology includes thorough procedures to separate the spending of incidental visitors.

\section{The Impact Studies Methodology}

There is a general consensus that whilst measures related to economic impact assessment are conceptually simple, the actual collection of such information is extremely difficult and time consuming (Bond, 2008). Economic impact studies are used to estimate the economic importance of big cultural or sporting events as well as important infrastructure projects. The effects of hosting big events are mainly evaluated in two fields. The first focuses on the short-term impacts which have wide diversity in their range of 
economic and intangible positive and negative effects on the city and local community. The second concentrates on the long-term impacts which concern the legacy of the construction of facilities and infrastructure improvements (Barghchi et al., 2009).

Well-developed economic impact studies involve several practical applications of the methodology e.g. the assessment of cultural events and festivals (Estonian Institute of Economic Research, 2012; Hill Strategies, 2003; Vrettos, 2006), cultural institutions (Economic Development Research Group, 2002; Bollo, 2013), and significant cultural projects e.g. European Capital of Culture (Herrero, 2006; Plaza et al, 2013). All of these studies have used similar steps of the universally recognized methodology for the estimation of local economic impact in the cultural sector. The local economic impact is presented by the quantification of the additional income to the local economy received by visitor spending due to visiting the event. The comprehensive methodology for economic impact analyses of cultural events was used for example in the evaluation of Salamanca European Capital of Culture 2002. (Herrero, 2006). An adjusted methodology was used to estimate the overall economic impact of the White night festival in Kosice.

According to Crompton (2010) the economic impact of visitor spending is estimated by the formula: number of visitors * average spending per visitor * multiplier. The number of visitors is clear in gated events (with controlled points of entry/exit). A more challenging task is counting the attendees at an ungated event. An "ungated" or open access event is one that takes place in a whole or in part of an open area where access is not controlled (Guidelines, 2007). The estimating process of the total attendance at an event faces a number of problems. People can come and go at different times and places and it is difficult to distinguish event attendees from passer-bys. Generating unduplicated counts of attendees and their characteristics requires special and complex procedures. Six approaches are discussed as tools for estimating attendance at ungated events: aerial photography; parking lot counts; parade counts; tag and recapture; entrance/exit counts; and accommodation data (Guidelines, 2007) The next problem is that the organisers tend to overestimate the number of visitors at an event, so called "attendance hyperbole" (Crompton, 2010).
There are three different types of measurable impacts (or effects) of the event: direct impact, indirect impact and induced impact. Direct impacts are directly related to cultural event expenditures, which were spent in the hosting city (or region) within the analysed period of time. These expenditures can be of a different kind (investment costs of cultural infrastructure or cultural equipment, salaries of employees organizing cultural events, cultural program expenditures etc.) It is very important to collect all the direct impacts, no matter what source they were funded from (public or private). To ensure the correct implementation of the methodology it is important to cleanse these costs from the expenses causing no additional economic activity within the analysed region (VAT, social insurance etc.).

Visitor impacts include all visitors spending directly related to the analysed cultural events including direct expenses for tickets, accommodation, restaurants etc. The source of this information is usually primary research among visitors. According to several authors (Crompton, 2010; Šipikal et al., 2010) not all visitor expenditure means new additional economic input for the region. The expenditure of local visitors, for example, would probably have been spent in the region even if the analysed cultural event had not taken place. Therefore, residential spending is completely excluded because it does not reflect new money in the local economy.

The main additional economic impact for the region comes from foreign and domestic visitors - tourists. Here again, the question is what proportion of visitor expenditure is directly related to the analysed cultural event? A tourist's main reason for visiting the city could be a business trip or visiting family and a cultural event could be only on the side. According to the basic principles of economic impact, it is important to identify a tourist's reasons for visiting the analysed locality. Herrero (2006) formulated a reducing coefficient to calculate expenditure based on a tourist primary motivation for visiting the analysed cultural event. The repetition coefficient enables the avoidance of duplicities in visitor spending.

Induced impacts are changes in the economy caused by the additional production of subcontractors as a result of further rounds of economic activity in the analysed region. These changes include all further rounds of 
production induced by backward linkages of direct suppliers and their subcontractors (Raabová, 2011). Through induced impacts, direct expenditure and visitor expenditure are reflected in all other sectors of the economy. The size of induced impact is proportional to the propensity of local firms to purchase inputs from regional suppliers. It is therefore crucial to select the correct methodology for induced impact quantification. Induced impacts of cultural events are usually estimated by regional multipliers. The multiplier concept recognizes that when visitors to a facility or event spend money in a community, their initial direct expenditure stimulates economic activity and creates additional business turnover, personal income, employment, and government revenue in the host community (Crompton, 2010) The induced impacts are calculated using several kinds of multipliers (e.g. Keynesian regional multiplier, multiplier based on Input-output (I-O) matrix) or econometric models as REMI or HERMIN.

There is an unambiguous lack of research about the economic aspects of the cultural sector especially about the economic effects of cultural events and infrastructure in Slovakia. It is grounded in poor data availability about culture as well as regional multipliers. The regional multipliers are not provided by statistical offices in Slovakia as in most of the CEE countries (Macháček et al., 2013). The regional multiplier used in this paper was calculated with the purpose of accurately evaluating the total economic impact of the Košice European Capital of Culture. The demanding calculation was provided by derivation multipliers from national I-O tables using Flegg's Local Quotient (Flegg et al., 1995). A detailed calculation of the regional multiplier was published in Hudec et al (2014).

\section{The Data Collection}

The aim of the paper is to estimate the economic impact of the White night on Košice. The choice of the study region was determined by the locality of the event. The analysis deals only with the impact of visitors' expenditure. The analysis of other direct impacts is not addressed because of the reluctance of the organisers to publish it.

The gathering of primary data was based on the methodology developed by the European policy group for the ECoC projects evaluation and on the methodology of economic impact assessment. The authors of the paper were directly involved in the evaluating process of the ECoC in 2012-2014. The findings of the evaluation process have been summarized in a report published by Hudec et al (2014). Two types of questionnaires were used in the robust primary research: event questionnaires and stationary questionnaires which in total amounted to 4607 . The event questionnaires were collected at selected cultural events organized under the Košice ECoC project during 2012-2014.

One of the investigated events was the White night festival. The survey aimed to estimate the socio-economic structure of the event audience, to evaluate the visitors' satisfaction and collect information about visitors' expenditure to evaluate the economic impact of the festival. During 2012, 360 questionnaires were collected and during 2012, 524 questionnaires were collected.

According to the previously mentioned methodology of local economic impact, the current research was carried out in several steps:

1. Estimation of the number of visitors attracted by the event.

2. Estimation of the average level of spending of visitors in the local area.

3. Calculation of the direct local economic impact of the event.

4. Multiplication by the regional multiplier and calculation of the total economic impact of the event.

\section{Results}

At the White Night, all performances were free and took place over the whole night, so the counting of attendees was labour intensive. The research methods for the estimation of the total attendance were a tally questionnaire and aerial photographs in 2012, and a tally questionnaire and parade count in 2013. Given that the tally information for an ungated event is instrumental in estimating total audience size as well as the proportion of attendees who are tourists and local residents, the research method was precise in the sampling and weighting processes.

In 2012 a methodology of the aerial photographs was used. In 2013 a modified methodology of "parade counts" was used, as described in the Guidelines (2007). It was predicted that the "parade" that would be 
expected to attract the "peak" attendance would be the newly reconstructed City Park, where the most beautiful light performances took place during the night. The reconstruction of the City Park was one of the main infrastructural projects carried out within the Košice ECoC 2013 projects. The City Park is surrounded by a fence with six entrances. Therefore, there was a possibility to count the people coming to the city park. According to the counting, 18,373 visitors entered the City Park between 7 p.m. and midnight. At the same time, a questionnaire survey was done among the White night visitors. One of the questions in the interviews was, whether the respondent already was or had planned to visit the City Park during the night. Our calculation of 21,613 White night attendees is derived from the combination of the counting in the City Park and the information that had been captured by the tally questionnaire. However, considerable attendance hyperbole was detected. The organisers reported around 50,000 attendees, while the current research estimated around 17,000 visitors in 2012 and 21,000 visitors in 2013.

The statistics provided by the National Statistical Office or City council include visitors who stay in a destination for one night or more (i.e. tourists) in recognised accommodation establishments. They do not provide full coverage of tourism activity as same-day visitors are not included, nor are visitors staying with friends and relatives. However, the research questionnaires are designated to capture these visitors too. The questionnaire was designed to obtain basic information about the origin, socioeconomic structure and expenditure of the visitors. The following chart (Tab. 1) shows the estimation about the visitors according to the geographical origin. As can be seen from the table, the majority of visitors came from Košice, and nearly $20 \%$ came from Slovakia. Only $5 \%$ of visitors originated abroad. Similar results were achieved in an impact study of the White night in Rome (Cherubini \& lasevoli, 2006) with only $6 \%$ of foreign visitors.

Tab. 1: Geographical origin of visitors who attended the White night festival

\begin{tabular}{l|c|c} 
& $\mathbf{2 0 1 2}$ & $\mathbf{2 0 1 3}$ \\
\hline Local visitors & 12,890 & 15,540 \\
\hline Slovak tourists & 3,210 & 4,410 \\
\hline Foreign tourists & 900 & 1,050 \\
\hline Total & 17,000 & 21,000 \\
\hline
\end{tabular}

Source: own

From table 2, it can be seen that around $51-55 \%$ of the attendees were male. The most attendees were between 21 and 30 years and secondary school-educated. According to the occupation almost $40 \%$ of the visitors were students. The demographics highlight the popularity of the festival among the younger generation in the city.

The White Night is organised in Košice on the first Saturday night in October every year. On Sunday morning the largest sport event starts, the Kosice Marathon, which is the oldest in Europe and has been organised since 1924. The synergy between the cultural and sporting attraction has resulted in vital tourism in the first October weekend. Local tourist providers have named it the "Golden Weekend" in Košice because all accommodation is usually fully booked. Therefore, visitors were asked about their reason for visiting Košice to separate the spending of visitors as a result of the White night and what would have occurred even if the White night had not been in Košice. The application of a reducing coefficient was based on the question: How important is this event for your visit to Kosice from 1 to 10 ? (10 - maximum importance) The reducing coefficient was calculated using the formula, where $t_{i}$ is the percentage of positive answers for one of the questions from the scale 1-10 (Herrero et al, 2006).

$$
C_{r e}=\sum_{i=1}^{10}\left(t_{i} \times 0,1 i\right)
$$

The reducing coefficient was much higher by foreign tourists in 2013. We assume that the 


\begin{tabular}{|c|c|c|}
\hline & 2012 & 2013 \\
\hline \multicolumn{3}{|l|}{ Gender } \\
\hline Male & $51 \%$ & $55 \%$ \\
\hline Female & $49 \%$ & $45 \%$ \\
\hline \multicolumn{3}{|l|}{ Age } \\
\hline $0-20$ & $19 \%$ & $18 \%$ \\
\hline $21-30$ & $46 \%$ & $47 \%$ \\
\hline $31-40$ & $11 \%$ & $15 \%$ \\
\hline $41-50$ & $8 \%$ & $10 \%$ \\
\hline $51-60$ & $10 \%$ & $6 \%$ \\
\hline 61 and more & $6 \%$ & $4 \%$ \\
\hline \multicolumn{3}{|l|}{ Education structure } \\
\hline Elementary education & $13 \%$ & $7 \%$ \\
\hline Secondary education & $53 \%$ & $55 \%$ \\
\hline Higher education - university degree & $34 \%$ & $38 \%$ \\
\hline
\end{tabular}

ECoC year attracted foreign students to visit Košice and join cultural festival.

In the next step the average spending of visitors was calculated in specific sectors of the local economy (accommodation, food, retail, transport etc.). The expenditure of local visitors from Košice was excluded from the analysis. It was assumed that their spending would have occurred in the local economy whether the White Night had happened or not. If local visitors had not attended a festival, they would have spent their money in a local venue at another time. This approach is used by most economic impact studies as previously mentioned.

The average expenditure of visitors was calculated and multiplied with the reducing coefficient. The result presented the visitors' impact on the local economy - the additional income of visitors' expenditure.

The average spending of a Slovak visitor was 38 Eur in 2012 and 45 Eur in 2013. The average spending of a foreign visitor was 95 Eur in 2012 and 110 Eur in 2013. Table 3 presents the expenditure of visitors according to the basic

\section{Tab. 3: Attribution of spending by visitors of the White night festival}

\begin{tabular}{l|c|c|c|c}
\multirow{2}{*}{} & \multicolumn{2}{|c|}{ Slovak tourists } & \multicolumn{2}{c}{ Foreign tourists } \\
\cline { 2 - 5 } & 2012 & 2013 & 2012 & 2013 \\
\hline Reduction coefficient & 0.71 & 0.7 & 0.45 & 0.65 \\
\hline $\begin{array}{l}\text { Reduced expenditures for accommodation and } \\
\text { food }\end{array}$ & 36,473 & 49,369 & 19,995 & 26,542 \\
\hline Reduced expenditure for retail & 29,607 & 37,385 & 4,794 & 30,333 \\
\hline Reduced expenditure for transport & 6,347 & 13,574 & 3,490 & 2,708 \\
\hline Total expenditure & 72,427 & 100,328 & 28,279 & 59,583 \\
\hline
\end{tabular}


groups of expenditure. The biggest spending occurred in the sector of accommodation and food. The direct economic impact of visitors spending in 2012 was $100,706 €$ and in 2013 it was $159,911 €$. The impact of the festival evidently increased in 2013 caused by higher attendance, higher spending of foreign tourists and higher reducing coefficient.
The last step was the calculation of the induced effects of visitor spending. The induced effects present the benefits gained in the local economic system derived from the primary expenditure of visitors. The induced impact was estimated through the concept of the regional multiplier following the methodology explained in the previous section. The regional

Tab. 4: The induced economic impact by visitors of White night festival

\begin{tabular}{c|c|c|c|c} 
& Output & Income & Employment & Value-added \\
\hline $\mathbf{2 0 1 2}$ & 168,970 & 35,819 & 2 & 73,974 \\
\hline $\mathbf{2 0 1 3}$ & 268,678 & 56,458 & 3 & 118,074 \\
\hline
\end{tabular}

input-output multiplier derived from the national Input-Output Tables of Slovakia was used for each economic branch separately. The results are presented in table 4.

The expenditure of visitors led to changes in demand in the local economy and thereby to the additional production of goods and services to the amount of 169,970 Eur in 2012 and 268,678 Eur in 2013. The income of people who worked in this additional production increased by 35,819 Eur in 2012 and 56,458 Eur in 2013. The employment multiplier expresses new jobs in the local economy. However, it is important to note that estimates done by employment multipliers estimate the increase in jobs measured as full-time job positions. A one night event probably didn't produce any full-time jobs, but it opened up more part-time jobs during the organisation and realisation of the festival. The growth of the local economy could be expressed by a value added multiplier which caused the increase of 73,973 Eur in 2012 and 118,074 Eur. This can be considered approximately as the increase in regional growth. As seen in table 4 , the economic impact of the festival based on visitors spending was much higher in the $\mathrm{ECoC}$ year 2013 compared to the year before.

\section{Conclusion}

One of the goals of the ECoC designation of Košice was to attract more tourists and stimulate vibrant cultural tourism in the city and closer region. The White Night festival has become one of the most popular cultural events organized by the team of ECoC in Košice since
2010. In order to evaluate the real benefits and compare them with the expectation is only possible with accurate data. This empirical study presents results from the research focused on the economic impact of the festival on Košice. Attendance hyperbole was suspected given the estimation of attendees made by the organisers. The real amount of yearly visitors was less than double what the organisers declared. Information about the amount and structure of visitors could have valuable benefits for the organisers to optimize the infrastructure and human sources by organizing the festival. The economic impact number shows the worthy new amount of money achieved in the local economy through a cultural event. The value of an economic impact study could help the organisers obtain special support from private and public sources.

The originality of this empirical study is in the used methodology. It is the first implementation of the methodology of economic impacts to a cultural event in Slovakia. The adjusted methodology and the matrix of calculated regional multipliers have enabled the replication of the methodology on other cultural events and facilities. The results of the empirical study can also establish the first step for further deeper analysis of economic aspects of cultural events in Slovakia.

According to the evaluation findings, the festival has primarily captured local residents and national tourists. Similar results have been found in other analysed events during ECoC 2013. In terms of what is important for cultural 
policy implications, it is vital to take into account the information about the increasing interest in street art culture and also the dominant participation of young people. The designation of European Capital of Culture has fomented vital cultural participation in Košice. It is visible not only in the organisation of various cultural events but also in further developing startups and spin-offs in the cultural and creative industries.

This paper was created within the project VEGA 1/0548/14 "Analysis of differences in innovation performance of spin-off and start-up firms in Slovakia"

\section{References}

Barghchi, M., Omar, D., \& Aman, M. (2009). Cities, Sports Facilities Development, and Hosting Events. European Journal of Social Science, 10(2), pp. 185-194.

Bollo, A. (2013). Measuring Museum Impacts. Bologna: Istituto per i Beni Artistici Culturali e Naturali.

Bond, H. (2008). Estimating the Economic Benefits of Event Tourism A Review of Research Methodologies. University of Manchester.

Castiglione, C., \& Infante, D. (2015). Rational addiction and cultural goods: the case of the Italian Theatregoer. Journal of Cultural Economics, 39, 1-28. doi:10.1007/s10824-015-9247-4.

Charles, A., \& Michelle, W. (2006). Festival Attendance and the Development of Social Capital. Journal of Convention \& Event Tourism, 8(2), 1-18. doi:10.1300/J452v08n02_01.

Cherubini, S., \& lasevoli, G. (2006). Stakeholders Event Evaluation: Notte Bianca Case Study. Convegno "Le Tendenze Del Marketing In Europa”. Università Ca' Foscari Venezia, 20-21 Gennaio 2006.

Crompton, J. (2010). Measuring the Economic Impact of Park and Recreation Services. Ashburn: National Recreation and Park Association.

Economic Development Research Group. (2002). Economic Impact of the Museum of Fine Arts, Boston. Boston: Economic Development Research Group.

Estonian Institute of Economic Research (2012). Assessment and analysis of the regional economic impact of cultural and sports events organized in Estonia. Estonia: Estonian Ministry of Culture.
Flegg, A.T., \& Tohmo, T. (2008). Regional Input-Output Models and the FLQ Formula: A Case Study of Finland. Bristol: Department of Accounting, Economics and Finance, Bristol Business School, University of the West of England.

Fleischer A., \& Felsenstein, D. (2002). Cost-Benefit Analysis Using Economic Surpluses: A Case Study of a Televised Event. Journal of Cultural Economics, 26(2), 139-156. doi:10.1023/A:1014447018099.

Garcia, B. (2004). Cultural Policy and Urban Regeneration in Western European Cities: Lessons from Experience, Prospects for the Future. Local Economy, 19(4), 312-326 doi:10.1080/0269094042000286828.

Gazel, R.C., \& Schwer, R.K. (1997). Beyond Rock and Roll: The Economic Impact of the Grateful Dead on a Local Economy. Journal of Cultural Economics, 21(1), 41-55. doi:10.1023/A:1007372721259.

Guetzkow, J. (2002). How the Arts Impact Communities: An introduction to the literature on arts impact studies. Princeton University: Center for Arts and Cultural Policy Studies.

Gursoy, D., Kim, K., \& Uysal, M. (2004). Perceived impacts of festivals and special events by organizers: An extension and validation. Tourism Management, 25(2), 171-181. doi:10.1016/S0261-5177(03)00092-X.

Hackbert, P., \& College, B. (2009). Economc Impacts of Appalachian Festivals. In Proceedings of ASBBS Volume 16 Number 1. ASBBS Annual Conference: Las Vegas.

Herrero, L., Sanz, J.A., Devesa, M., Bedate, A., \& Barrio, M.J. (2006). The economic impact of cultural events. A case study of Salamanca, European Capital of Culture. European Urban and Regional Studies, 13(1), pp. 41-57. doi:10.1177/0969776406058946.

Hill Strategies. (2003). Economic Impacts of 97 Festivals and Events. Ontario: Ontario Arts Council and the Ontario Cultural Attractions Fund.

Hudec, O., Džupka, P., Šebová, M., \& Gontkovičová, B. (2014). Evaluácia Košice Európske hlavné mesto kultúry 2013. (Evaluation Report of Košice ECoC 2013).

Lähdesmäki, T. (2012). Impacts of the European Capital of Culture designation on regeneration of city space. Retrieved from http://www.inter-disciplinary.net/at-the-interface/wp-content/uploads/2012/01/TuuliL\%C3\%A4hdesm\%C3\%A4ki-IC5-2012.pdf. 
Macháček, J., Silovská, H., Říhová, G., \& Jílek, P. (2013). Regionální multiplikační efekt jako indikátor lokálniho rozvoje. E\&M Ekonomie a Management, 16(3), 20-32.

Navrud, S., \& Ready, R.C. (2002). Valuing Cultural Heritage. Applying Environmental Valuation Techniques to Historic Buildings, Monuments and Artifacts. Edward Elgar Publishing Ltd.

O'Sullivan, D.O., \& Jackson, M.J. (2002). Festival Tourism; A Contributor to Sustainable Local Economic Development. Journal of Sustainable Tourism, 10(4), 325-342. doi:10.1080/09669580208667171.

OECD (2009). The Impact of Culture on Tourism. Paris: OECD. Retrieved from: https:// www.oecd.org/cfe/tourism/42040148.pdf.

Palma, M.L., Palma, L., \& Aguado, L.F. (2013). Determinants of cultural and popular celebration attendance: the case study of Seville Spring Fiestas. Journal of Cultural Economics, 37(1), 87-107. doi:10.1007/s10824012-9167-5.

Plaza, B., \& Banos, G. (2013). Economic Impact Evaluation of European Capitals of Culture (Working Paper). Universidad del País Vasco. Retrieved from http:// www.reunionesdeestudiosregionales.org/ Oviedo2013/htdocs/pdf/p745.pdf.

Quinn, B. (2006). Problematising 'Festival Tourism': Arts Festivals and Sustainable Development in Ireland. Journal Of Sustainable Tourism, 14(3), 288-306. doi:10.1080/09669580608669060.

Raabová, T. (2011). Návrh certifikované metodiky pro výpočet ekonomických dopadů kulturní organizace. Praha: Institut umění Divadelní ústav, 2011.

Research Resolutions \& Consulting Ltd. (2007). Guidelines: Survey Procedures for Tourism Economic Impact Assessments of Ungated or Open Access Events and Festivals. Retrieved from http://www.mtc.gov.on.ca/en/ research/resources/Guidelines_Econ_Impact_ Ungated_Events_2007.pdf.

Richards, G. (Ed.). (2005). Cultural tourism in Europe. ATLAS.
Sanz, J.Á., Herrero, L.C., \& Bedate, A.M. (2003). Contingent Valuation and Semiparametric Methods: A Case Study of the National Museum of Sculpture in Valladolid, Spain. Journal of Cultural Economics, 27(3-4), 241-257. doi:10.1023/A:1026353218280.

Slach, O., Koutský, J., Novotný, J., \& Ženka, J. (2013). Creative industries in the Czech Republic: a spatial perspective. E\&M Ekonomie a Management, 16(4), 14-28.

Stanley, D., Rogers, J., Smeltzer, S., \& Perron, L. (2000). Win, Place or Show: Gauging the Economic Success of the Renoir and Barnes Art Exhibits. Journal of Cultural Economics, 24(3), 243-255. doi: 10.1023/A:1007652201187.

Sucháček, J., \& Sed’a, P. (2011) Territorial Marketing in the Czech Republic: Between PathDependency and Learning. In: Proceedings of the 10th International Conference Liberec Economic Forum 2011 (pp. 439-447). Liberec: Technical University of Liberec.

Šipikal, M., Rehák, Š., \& Labudová, V. (2010). Metódy a techniky regionálnej analýzy. Praktikum. Ekonóm.

Tyrrell, T.J., \& Johnston, R.B. (2011). A spatial extension to a framework for assessing direct economic impacts of tourist events. In S. Page, \& J. Connell (Eds.), Handbook of Events, Chapter: 22 (pp.329-346). Taylor and Francis.

Vrettos, A. (2006). The Economic Value of Arts \& Culture Festivals/ A Comparison of four European Economic Impact Studies. Maastricht: University of Maastricht, 2006.

doc. Ing. Peter Džupka, PhD. Technical University of Košice Faculty of Economics Department of Regional Science and Management Peter.Dzupka@tuke.sk

Ing. Miriam Šebová, PhD. Technical University of Košice

Faculty of Economics Department of Regional Science and Management Miriam.Sebova@tuke.sk 


\section{Abstract}

\section{LOCAL ECONOMIC IMPACT OF THE WHITE NIGHT FESTIVAL IN KOŠICE}

\section{Peter Džupka, Miriam Šebová}

Košice is the second biggest city in Slovakia. In the last 25 years (following the period of Communism) Košice has passed through several waves of transformation involving economic, social and urban changes. Košice was awarded the European Capital of Culture (ECoC) in 2013. The winning project was based on the city transformation through culture and support of the creative economy (startup and spin-off firms). Big cultural events have not only cultural and social benefits, but also an indisputable economic impact on the hosting city. These events represent an opportunity to not only attract visitors from outside the region but also for them to spend money on accommodation, food, transport etc. Visitors' expenditure presents additional income for the local economy and stimulates a considerable amount of economic activity and growth. The assessment of the economic impact of events has become popular of late and combines the economic approach with spatial marketing and tourism studies. A coherent methodology has also been developed to evaluate the economic impact of events in the geographical area.

This paper aims to estimate the local economic impact of the biggest cultural event organised in Košice, the White Night festival, a spin-off of the Košice European Capital of Culture 2013. This impact empirical study was done in three stages. Firstly, the measurement of attendees using appropriate methods for ungated events. Secondly, the estimation of the visitors' impact related to private spending generated by the event's visitors and thirdly, through estimating the overall economic impact by calculating the multiplying effects on the local economy (induced impacts). The study was based on research conducted during 2012 and 2013 in Košice. The result shows the attendance hyperbole and impact of visitor spending that was due to the festival in the local economy.

Key Words: Economic impact, cultural economics, induced effects, regional multipliers.

JEL Classification: O18, Z1.

DOI: 10.15240/tul/001/2016-2-009 